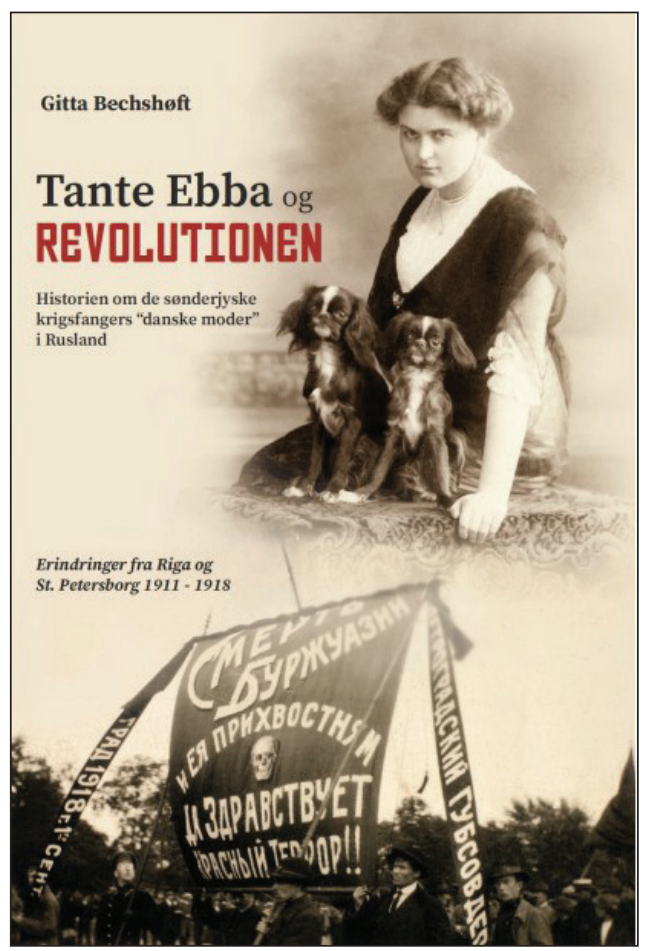

\title{
Tante Ebba og Revolutionen: Historien om de sønderjyske krigsfangers «danske moder» i Rusland
}

\author{
Gitta Bechshøft \\ København: Historia 2020 \\ 236 sider. ISBN 9788793846869
}

Omtalt av Jens Petter Nielsen [professor emeritus ved UiT Norges arktiske universitet, jens.petter.nielsen@uit.no]

Denne boka må sies å være frukten av en tilfeldighet, nemlig funnet av et upublisert manuskript i forbindelse med et slektshistorisk prosjekt. Det er en øyenvitneberetning fra Den russiske revolusjon, skrevet av en fjern slektning av Gitta Bechshøft, som er kvinnen bak dette bokprosjektet. Det upubliserte manuskriptet er skrevet av Ebba Tramp Bechshøft, og er basert på hennes opplevelser i årene 1911-1918. På den tid bodde hun og hennes mann, som var direktør i Dansk Russisk Handelskompagni, først i Riga, og senere i St. Petersburg/Petrograd, den gang Russlands hovedstad, der de ble medlemmer av en liten «dansk koloni». Her opplevde de revolusjonen på nært hold. Ebba Tramp Bechshøfts manuskript, som utgjør ca. halvparten av boka slik den foreligger, handler i stor grad om hennes hjelpearbeid for sønderjyske krigsfanger i Russland. Gitta Bechshøft har så utviklet dette temaet videre i den andre halvdelen av boka, der vi finner ytterligere informasjon om disse krigsfangenes skjebne - på basis av danske kilder. Boka er rikt illustrert med samtidige fotografier fra den aktuelle perioden, samlet inn fra ulike kilder i Danmark.

Tante Ebba og Revolutionen er interessant lesning av flere grunner: For det første har vi å giøre med en sjelden øyenvitneberetning om Den russiske revolusjon fra et 
skandinavisk kommersielt miljø i Russland. I tillegg er boka skrevet av en kvinne som tydeliggiør de begrensede muligheter kvinner hadde til å gjøre seg gjeldende i denne bransjen. "Tante Ebba» har skrevet en dramatisk og medrivende beretning om revolusjonen i Petrograd, men det mest interessante temaet hun tar for seg er likevel skjebnen til de hundrevis av unge menn fra Sønderjylland, som den første verdenskrigen hadde brakt til Russland. De kom fra den delen av Danmark som etter krigen i 1864 ble en del av Preussen og de ble alle innrullert i den tyske hær og kjempet under første verdenskrig på Tysklands side (mot sin vilje må vi tro, i de fleste tilfeller). Ca. 300 av dem ble tatt som krigsfanger av russiske avdelinger og havnet i fangeleirer i Russland. Ettersom disse soldatene var danske «i kropp og sjel», og ikke tyske, var spørsmålet hvordan man skulle få dem satt fri fra fangenskapet og sendt tilbake til Danmark?

I denne historien, som vel er lite kjent utenfor Danmark, spilte Ebba Tramp Bechshøft en viktig rolle, og det var ikke uten grunn at hun ble omtalt som krigsfangenes «danske moder» i Russland. Denne betegnelsen kunne vel med full rett også anvendes på enkekeiserinne Maria Fjodorovna (Dagmar), datter av den danske kong Christian 9, og mor til tsar Nikolaj 2. Hun skal ha overtalt sin sønn til å tillate at de sønderjyske krigsfangene ble samlet i egne leirer, og det skjedde også til en viss grad. Den viktigste av disse leirene var i Jurjev-Polskij, en by i Vladimir-guvernementet, øst for Moskva. Danskene fikk bedre betingelser enn andre krigsfanger, og de fikk langt på vei rå seg selv. "Tante Ebba» sørget for at noen av dem ble ansatt av Dansk Russisk Handelskompagni til forskjellige jobber i fyrst Saltykovs herskapshus i Petrograd, som handelskompaniet leide etter at fyrst Saltykov selv hadde flyktet fra revolusjonen og søkt tilflukt i Finland.

Mens Maria Fjodorovna måtte holde seg innenfor loven, kunne Ebba Tramp Bechshøft også ty til ulovlige metoder, noe som måtte til hvis det skulle lykkes å sende de "sønderjyske drenge» tilbake til trygghet i Danmark. Det var ingen enkel sak å sende dem tilbake til det nøytrale Danmark når de var tyske statsborgere. De kunne ikke vende tilbake til Nord-Slesvig, som jo fremdeles var en del av Tyskland, og tyske myndigheter var etter fredstraktaten med Lenins regjering i Brest-Litovsk i mars 1918 antakelig ute etter å slå kloa i dem for å sette dem inn i kampene på vestfronten. Sønderjydene kunne ta foreløpig opphold i andre deler av Danmark så lenge krigen varte, men for å få dette til, måtte de utrustes med falske pass.

Grunnlagsdokumenter for slike pass var dåpsattester, som ble samlet inn fra privatpersoner i Danmark og smuglet inn i Russland på forskjellige sinnrike måter. Først etter at krigen var over kunne de «sønderjyske drenge» vende tilbake til sin hjemstavn, og folkeavstemningen i 1920 førte som kjent til at Sønderjylland/NordSlesvig igjen ble dansk.

«Tante Ebbas» erindringer står på egne bein som øyenvitneberetning, men som historisk verk om de sønderjyske krigsfangene under første verdenskrig lider de av store mangler. For å bøte på det har Gitta Bechshøft hentet informasjon fra det hun kaller Ebba Tramp Bechshøfts danske «medsammensvorne» i arbeidet for 
krigsfangene - og deres beretninger/erindringer som ble publisert i 1920-årene. Det er bøkene til "gymnastikkdirektør» Niels Hansen Rasmussen, som arbeidet for de danske krigsfangene over hele Europa, pastor Niels Anton Jensen, som i Russland påtok seg et spesielt ansvar for sønderjydene og var bindeledd mellom dem og danske myndigheter, Erik Plums bok om Dansk Russisk Handelskompagni, og andre. Til slutt slipper også fangene selv til med sine beretninger. Andre halvdel av boka inneholder således mange data og utdrag / lange sitater som listes opp litt hulter til bulter, dessverre med en god del gjentakelser. Det er til stor hjelp for leseren at forfatter/redaktør Gitta Bechshøft kommenterer stoffet underveis, men det hadde vært bedre om hun i stedet gav en samlet historisk oversikt, der disse dataene fikk sin logiske plass i en gradvis kronologisk fremstilling. Det er likevel verdifullt at så mye materiale om de sønderjyske krigsfangene i Russland under første verdenskrig er samlet på ett sted og dermed har blitt lett tilgjengelig for dem som ønsker å sette seg inn i saken. Det er også et stort pluss for boken at Gitta Bechshøft, på samme måte som sin fjerne slektning, Ebba Tramp Bechshøft, er en dyktig skribent. 